\title{
車両感知バイアスのオンライン自動補正 \\ ONLINE AUTOMATIC CORRECTION OF VEHICLE DETECTION BIAS
}

\author{
赤羽弘和*・越 正毅** \\ By Hirokazu AKAHANE and Masaki KOSHI
}

\begin{abstract}
This paper deals with a method of on-line automatic updating of the correction factors for vehicle detection bias. The factors are given for free flow and congested flow individually at each of expressway cross sections based on the traffic data that are obtained from vehicle detectors. This updating method was tested through the use of traffic data that were collected from Tokyo Expressway.

Keywords : vehicle detector, bias correction, traffic control, parameter updating, Kalman filter
\end{abstract}

\section{1. はじめに}

都市高速道路の管制システムにおいては, 車両感知器 からの情報を処理することにより交通量, 速度, 時間才 キュパンシーなどの交通状態量が算出されている. そし て,これらの交通状態量を総合することにより道路網全 体の交通状況が把握され，それに基づいて流入制御や交 通情報の提供などの交通流制御が実施されている. した がって, 交通管制を効果的に行うためには, 交通状態量 を車両感知器により正確に計測することが必要である.

都市高速道路および一般街路における調查・解析 ${ }^{1) \sim 5}$ によれば, 車両感知器による通過車両台数の計数値には, 補正を要するほよ゙に大きな偏りが含まれることがある.

たとえば，車両が車線変更の際に車線境界をまたいで感 知器設置断面を通過することが, 偏りの発生要因の 1 つ に挙げられている.この場合, 車両感知器の横方向の感 知範囲が広い場合には, 走行および追越し車線の感知器 の双方により，このような車両が重複して感知される度 合いが大きくなり，通過台数は実際より過剩に計数され

* 正会員 工博 千葉工業大学講師 土木工学科 （テ275 習志野市津田沼 2-17-1)

** 正会員 工博 東京大学教授 生産技術研究所 （宁106 港区六本木 7-22-1）
る. 逆に横方向の感知領域が小さい場合には, どちらに も感知されない度合いが大きくなり，過小計数となる. また, 同様に車両感知器の感知特性によっては, 大型車 が感知されなかったり, 特殊な形状の車両が 2 台以上に 感知される場合が多くなることなども, 偏りの発生要因 に挙げられている.

この偏りの大きさや, 過剩計数あるいは過小計数にな るのかは, 感知器自体の特性, その設置状況, あるいは 交通状況などに依存する. したがって, 偏りを補正する ための係数值も, 各感知器設置断面ごとに設定する必要 がある. また, 感知器の特性あるいは交通状況の経年変 化に従い, それらの計数值を継続的に更新していくこと も必要である.これまでにも目視観測に基づいて補正係 数値を設定した例 ${ }^{5)}$ はあるが, 都市高速道路には多数の 車両感知器が設置されており, 補正係数值を各断面ごと に人手によりオフラインで設定あるいは更新することは きわめて困難である. そこで本研究においては, 通過台 数の計数值を補正する方法を提案するとともに，この補 正に用いる係数值を車両感知器データに基づいて自動的 に設定・更新するオンラインアルゴリズムを開発した.

\section{2. 車両感知の偏り}

本章においてはループ式車両感知器を中心に述べる 
表一1 ループ式車両感知器の計数精度

\begin{tabular}{|c|c|c|c|c|c|c|}
\hline \multirow{2}{*}{ 调卒 } & \multirow{2}{*}{$\begin{array}{l}\text { 酒遗 } \\
\text { 台数 } \\
\text { (1) }\end{array}$} & \multicolumn{2}{|c|}{ 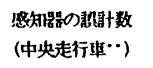 } & \multicolumn{2}{|c|}{ 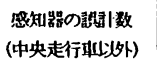 } & \multirow{2}{*}{ 倩者 } \\
\hline & & 台数 & $\begin{array}{l}\text { のに対する } \\
\text { 新合(x) }\end{array}$ & 白数 & $\begin{array}{l}\text { のに対する } \\
\text { 揢合 }(x)\end{array}$ & \\
\hline \multirow{2}{*}{1} & \multirow{2}{*}{2138} & $34(+)$ & 1.4 & $2(t)$ & 0.1 & \multirow{4}{*}{ 帮落部 } \\
\hline & & $0(-)$ & 0.0 & $7(-)$ & 0.3 & \\
\hline \multirow{2}{*}{2} & \multirow{2}{*}{2197} & $29(+)$ & 1.3 & $2(+)$ & 0.1 & \\
\hline & & $0(-)$ & 0.0 & $6(-)$ & 0.3 & \\
\hline \multirow{2}{*}{3} & \multirow{2}{*}{2175} & $61(+)$ & 2.8 & $0(+)$ & 0.0 & \multirow{4}{*}{ トンネル内部 } \\
\hline & & $0(-)$ & 0.0 & $8(-)$ & 0.4 & \\
\hline \multirow{2}{*}{4} & \multirow{2}{*}{3254} & $19(+)$ & 0.6 & $0(t)$ & 0.0 & \\
\hline & & $0(-)$ & 0.0 & $14(-)$ & 1.1 & \\
\hline \multirow{2}{*}{5} & \multirow{2}{*}{1870} & $16(+)$ & 0.9 & $3(+)$ & 0.2 & \multirow{4}{*}{ 合流点赫掼 } \\
\hline & & $0(-)$ & 0.0 & $2(-)$ & 0.1 & \\
\hline \multirow{2}{*}{6} & \multirow{2}{*}{1341} & $14(+)$ & 1.0 & $1(+)$ & 0.1 & \\
\hline & & $0(-)$ & 0.0 & $4(-)$ & 0.3 & \\
\hline
\end{tabular}

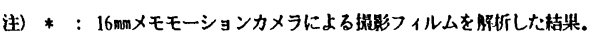

中：車橉境界をまたいで赾した車耐を示す。

(+)：1台の本雨を2台以上に的的する過制新数を示す。

$(-)$ ：不感知による递小計数を示す。

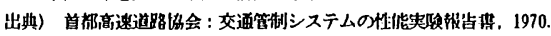

が，これと並んで実用に供せられることの多い超音波式 感知器についても状況は同様である.

表一1に, ループ式車両感知器による通過車両台数の 計数精度に関する調査結果を示す. 計数誤差の原因とし て, 以下が挙げられている1).

（1) 車線境界をまたいだ走行：表一1をみると，車 線変更などのために車線境界をまたいで走行する車両 （中央走行車）は，すべて走行車線および追越車線の車 両感知器の双方により感知されている.したがって, 断 面通過台数の計数值は, ほとんよ゙の調査断面において常 に過剩である. また，中央走行車による計数誤差の大き さは各断面によりかなり異なり，1\%末満の断面もあれ ば $3 \%$ 近い断面もある.

より一般的には，この偏りの大きさや過㮃計数になる のかあるいは過小計数になるのかは通行車両の車種, 走 行速度, 走行軌跡なよ゙の交通状況之, 感知器の設置状況 や感度分布に依存すると考えられる.

都市高速道路においては入出路の取付間隔が都市間高 速道路と比較して短く, また本線の右側に流出入ランプ が取り付けられている箇所もわが国では珍しくない．さ らに, インターチェンジの設置間隔も相対的に短い。し たがって，交通の流出入あるいは分合流に伴う車線変更 の発生頻度が，都市間高速道路と比較してかなり多いた め, それに起因する通過台数の計数值の偏りも相対的に 大きいと考えられる.

(2) 大型車：図一1 の例において, 乗用車の感知幅 をループ幅と等しくするには，同図中に横実線で示すよ うに, 約 $4 \%$ 以上のインダクタンス変化を検出すれば よいが，この感度設定では $6 \mathrm{t}$ ダンプは検出できない.

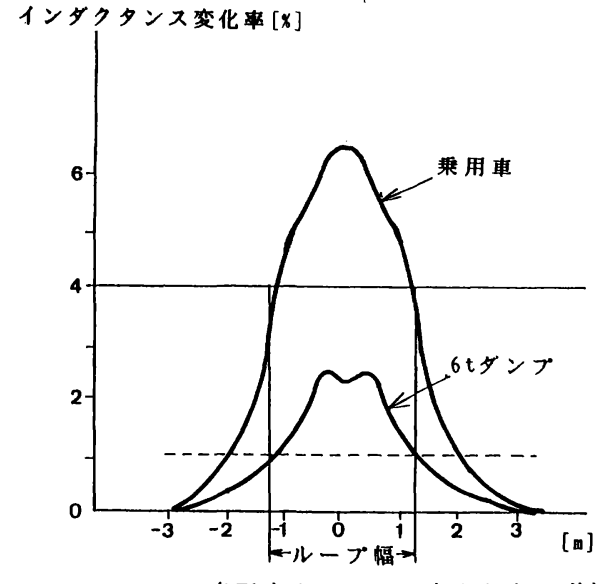

車雨中心のループ中心からのずれ

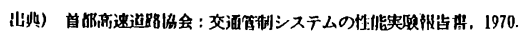

図-1 ループ式車両感知器の感度分布横断面図

一方，横破線で示すように，感度を約 $1 \%$ にすれば $6 \mathrm{t}$ ダンプの感知幅をループ幅と等しくできるが，こんどは 乗用車の感知幅がおよそ 2 倍に拡大してしまう．こうな ると，隣接車線を走行する車両までも感知してしまうお それがある.したがって，実際にはあまり高感度にする ことはできないため, 大型車は乗用車に比べて検出され ない可能性が高くなる.

(3) 多軸車：多軸車は車体下面と道路面との間隔が 大きいうえに, 各車軸がループ上を通過するたびに感知 出力にピークが生ずる.このため, 1 台の多軸車が, 2 台以上に感知されることがある.この過㮃計数の発生頻 度も, 感知器の感度を高めれば低減できる. しかし, (2) と同様の理由から実際にはあまり感度を高くすることは できない.

(4) その他： 先行車が感知範囲から離脱する前に後 続車が同一感知器の感知範囲にさしかかる場合や, 二輪 車の走行によっても偏りが発生する場合があることが報 告されている.

一般街路に設置された感知器については，以下のよう な実験報告4)がある.

(1) 計数値の偏り (相対誤差) は，ピーク時間帯およ び日中のオフピーク時間帯とでは異なる.

(2) それぞれの時間帯における偏りの時間変動は, 交 通量が変動しているにもかかわらず,ごくわずかである. したがって, 偏りの発生状況は, 交通量の変動にほとん ぞ依存しない。

(3) 偏りは，地点によりまちまちである.

両時間帯における偏りが異なるのは, ピーク時間帯に おける交通密度が相対的に高いことが，主要な原因であ ると考えられる．これは，交通流の密度が高いときと低 
いときとでは, あるいは速度が低いときと高いときとで は，車両の走行挙動がかなり異なるからであろう。

画像処理技術などを応用すれば，計数值の偏りがきわ めて小さい計数装置を開発することは可能であろう。し かし，すでに設置されている感知器をすべてこのタイプ の計数装置に置き換えることは, 費用などの面からも難 しい. したがって, 現用のループ式あるいは超音波式車 両感知器の計数値を補正して利用することが，現実的な 方策である.

\section{3. 補正係数値のオンライン自動管理の必要性}

車両感知器による通過台数の計数値の偏りの発生は, 2.において述べたように道路・交通条件に依存する. 以下に示すように，これらの条件は路線上の各地点で異 なるため, 偏りの発生状況も感知器設置断面により異な ると考えられる。

(1) たとえば，車線変更は分流点および合流点の前後 において特に多く発生する.その他の車両の走行状況も， 地点により異なる.

(2) 大型車あるいは特殊形状車などの混入率は，各路 線上を流れる交通の特性により異なる.

(3) たとえば, ループ式車両感知器の感知特性は, 路 面の摩耗あるいは損傷などの影響を受けて，時とともに 変化する. そして, 路面状態の変化は地点により異なる. したがって, 感知特性には, 設置時に適切に調整されて いても, 時とともにばらつきが生じてくる.

したがって, 通過台数の計数值の補正係数值は, 各感 知器設置断面ごとに設定する必要がある.

偏りの発生状況は, 以下に示す原因により経年変動す ると考えられる.

(1) OD パターンは，季節的に変動する．また，道路 網の拡張や沿線の開発などによっても変化する. OD パ ターンが変化すると, 各合流部, 分流部における車線変 更の発生状況, 大型車混入率なども変動する.

(2) 感知器の特性は経年変化する.

したがって, 補正係数值は, 継続的に見直されていか なければならない。

首都高速道路において昭和 60 年から導入されている 新交通管制システム（システム 60 ) では, 最終的に 2000 か所以上に車両感知器が設置される計画である ${ }^{6)}$. このように多数の車両感知器に対して, 人手によりオフ ラインで，しかも個別に補正係数值を設定あるいは更新 することはきわめて困難である.したがって，これらの 係数値をオンラインで自動的に管理するシステムが不可 欠である.

\section{4. 偏りの補正方法}

式（1）に示すように, ある感知器設置断面を通過す る車両台数の計数値を, 橴滞時または非渋滞時用の補正 係数をかけて補正することにする.

$$
\rho_{l}(t)= \begin{cases}c_{l} m_{l}(t) & \text { [非渋滞時] } \\ d_{\imath} m_{l}(t) & \text { [潵滞時 }]\end{cases}
$$

ここに, $m$ は単位時間内の断面通過台数の計数值, $\rho$ は計数値 $m$ の補正值, $t$ は時間, $c$ は非渋滞時補正係数, $d$ は渋滞時補正係数, そして添字 $l$ は上流から順に附番 された断面番号を示す.

補正係数を断面ごとに，かつ䠈滞時および非渋滞時の 別に設定する必要性は，前章で述べたとおりである.

各出路からの流出台数は本線通過台数の高々数 \% 之 わずかであるため,その計数值は補正しないこととした.

本線料金所および一般入路料金所において計数された 流入台数は，料金徴収結果と常に照合され，それに基づ いて感知特性が調整されている. さらに, 料金所を通過 するときの車両の走行軌跡はほぼ一定であり, 感知器の 感知範囲のほぼ中央を車両が通過している．このため, 流入台数の計数值は実用上十分に高精度であり，補正を 必要としない.そこで, 次の 5. において示すように, 流入台数の計数值を補正計数を推定する際の基準値とし て用いることにする.

渋滞の有無以外にも, 偏りの発生要因は時間変動する. したがって，たとえば大型車混入率や分流比率，合流比 率の変動に合わせて，時間帯別に補正係数を設定するこ とも考えられる. そして, それらの補正係数にも, 次章 以降で述べるアップデイティングアルゴリズムを適用す ることは容易である．ただし，時間帯別に補正係数を設 定することによる効果, あるいは時間帯の設定方法など については, さらに検討する必要がある.

\section{5. 補正係数のアップデイティング法) 99}

本章においては, 車両感知器データに基づいて, 通過 台数の計数値の補正係数をオンラインで自動的に更新す るアルゴリズムについて述べる. 補正係数の初期設定值 の精度が多少低くとも，この自動更新アルゴリズムによ りその精度を逐次改善していけば，やがては実用上十分 な精度が得られ，さらにその精度を維持していくことが できる.

\section{（1）各断面における計数值の比較}

図一2に示すような間に車両の流出入のない 2 断面に おいて, 通過車両台数の感知器計数値を比較することを 考える. 計数開始時と終了時の両断面間（区間内）の車 両台数が等しければ，すなわち区間密度が等しければ， その間の区間密度の時間変動にはかかわりなく, 計数時 


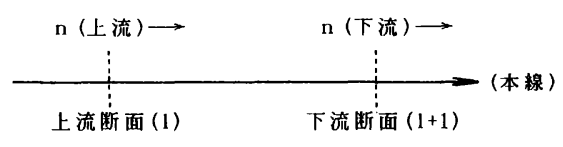

図一2 道路区間

間内にそれぞれの断面を通過する車両台数も等しくな る. したがって, 両断面における感知器計数值を直接比 較することにより, 計数值の偏りの相対的関係が得られ る. しかし，一般には計数開始時と終了時とで区間密度 は等しくはならないし，また等しくなるように計数時期 を調整することも実際には困難である，なぜなら，区間 密度あるいは区間内の存在台数を, 車両感知器により直 接測定することはできないからである。 また，図一3は 首都高速道路における交通量と交通密度との関係を例示 したものであるが, 同じ交通量に対しても交通密度は変 動する. したがって, 交通量を基準にして計数時期を調 整しても, 計数開始時と終了時とで区間密度を等しくす ることはできない.

計数開始時と終了時における区間内の車両台数が異な ると, 計数時間内に 2 断面を実際に通過する車両台数に も差が生ずる.この影響をでき得るかぎり小さくするた めに, 以下のような対策をとる.

(a) 隣接する断面間において計数値を比較する.

(b) 1 時間以上連続して計数した通過台数を比較す る.

(C) 隣接する 2 断面間において渋滞が発生していない ときに計数を開始する. また，同断面間において渋 滞が発生していないときに計数を終了する.

区間密度の変動による通過台数差は区間長に比例する ため，なるべく近接した断面間において計数值を比較す る必要がある.したがって，実用的には隣接する 2 断面 間において通過台数の計数值を比較することが適当であ る.

計数時間内の通過台数は計数時間の長さにほぼ比例す るから, 計数時間を長くすれば区間密度差の影響は相対 的に低下する. しかし，オンライン処理においては記憶 容量が制限されることや車両感知器の故障などもあるた め, 所要精度の達成に必要な長時間連続計数を, すべて の断面において実行するのは困難である．したがって， 最短計数時間を 1 時間とした。

図一3 中の斜線は, 自由流と渋滞流の境界を示してい る. 自由流における交通密度は, 交通量に応じておおむ ね $0 \sim 40$ 台 $/ \mathrm{km} /$ 車線の範囲内を変動している.これに 対して, 渋滞流における交通密度の変動範囲はおおむね $30 \sim 120$ 台 $/ \mathrm{km} /$ 車線であり, 変動幅は自由流の 2 倍以 上である.さらに, 同じ交通量に対する密度の変動幅も,

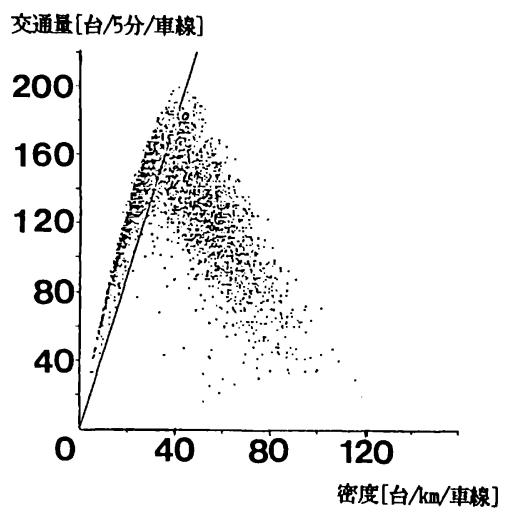

図一3 交通量-密度相関の例（首都高速）

自由流では 10 台 $/ \mathrm{km} /$ 車線程度であるのに対し, 跤滞流 ではおよそ 35 台 $/ \mathrm{km} /$ 車線にもなる．このような交通流 の特性から, 交通が渋滞していないときに計数を開始し, かつ交通が渋滞していないときに計数を終了させれば, 渋滞時に計数を開始あるいは終了させる場合よりも, 計 数開始時と終了時との区間密度差を小さくできる.

区間密度差を自由流の密度変動幅 40 台 $/ \mathrm{km} /$ 車線の 高々 $50 \%$, 計数時間内の平均交通量を 100 台/5 分/車 線 (1200 台/時間/車線), 区間長を首都高速道路の平均 感知器設置間隔である $0.6 \mathrm{~km}$ (デー夕収集当時), 通過 台数の最短計数時間を 1 時間と仮定すると, 両断面にお ける通過台数差, すなわち区間内の車両台数の差が計数 時間内の総通過台数に占める割合 (相対誤差) は, 以下 に示すように高々 $1 \%$ となる.

$$
\text { 相対誤差 }=\frac{\text { 区間密度差 } \cdot \text { 区間長 }}{5 \text { 分間平均交通量 } \cdot(60 \text { 分 } / 5 \text { 分 })}
$$

$$
=\frac{(40 \times 0.5) \times 0.6}{100 \times 12}=1[\%]
$$

さらに以下のような理由により，実際には相対誤差は $1 \%$ をかなり下回ると考えられる.

(1) 後述のように交通データの処理周期を 1 日とした ため, 感知器に障害が発生した場合などを除けば, 通常 は夜間の同一時間帯に計数を開始しかつ終了することに なり, 両時点における交通量の差はそれほど大きくはな らないと期待される. また, 通常は 24 時間連続して計 数できる.

(2) 車両感知器の設置間隔は現在すでに $300 \mathrm{~m}$ に なっており, 各区間内の車両台数の変動幅は半減してい る.

\section{(2) 補正係数の推定問題の定式化}

本節では, 前節 $(1)$ に示した通過台数の計数値の比 較法を応用するとともに，オンランプあるいは本線料金 所からの流入台数の計数值を基準值として用いることに 
より, 感知器計数值の補正係数を未知数とする連立方程 式を定式化する.

式 (1) によりある断面における通過車両台数の計数 値を補正したとき, 次式が成り立つような補正係数を推 定する.

$$
n_{l}(t)=\rho_{l}(t)+\zeta_{l}(t)
$$

ここに, $n_{l}(t)$ は単位時間内の断面通過台数の真値で あり, $\zeta_{l}(t)$ は通過台数の補正誤差である. 偏りの期 待值は補正係数により補正できるが, その期待值まわり の偶然誤差は車線変更の発生状況などの時間変動, ある いは感知器の特性に依存して補正後も発生する。この補 正後も残存する偶然誤差, すなわち補正誤差 $\zeta_{l}(t)$ を, 平均値 0 の白色雑音であると仮定する.

本線上に隣接する 2 断面 $l$ および $l+1$, そしてこの 断面間の流出入路において計数された通過台数につい て, 次の関係が成り立つを仮定する.

$$
\sum_{t=s l}^{u_{l}}\left\{n_{l}(t)-n_{l+1}(t)+i_{l}(t)-o_{l}(t)\right\}+\eta_{l}=0
$$

$s_{l}$ は連続計数開始時刻, そして $u_{l}$ は連続計数終了時 刻, $i_{l}(t)$ は断面 $l$ 断面 $l+1$ の入路または本線料金 所からの単位時間内の流入台数の計数値, そして $o_{l}(t)$ は断面 $l \sim$ 断面 $l+1$ の出路からの単位時間内の流出台 数の計数值である. $\eta_{l}$ は計数開始時および終了時にお ける区間内の車両台数差, および $i_{l}(t)$ と $o_{l}(t)$ の計 数誤差に起因する誤差項である. 計数開始時刻 $s_{l}$ およ び計数終了時刻 $u_{\imath}$ は, 区間内の車両台数差に起因する 誤差がなるべく小さくなるように, 前節（1）に示した 規準(a) (Cに基づいて決めることとする. そのうえで, 誤差項 $\eta_{l}$ は平均値 0 の白色雑音項の和であり, したがっ て $\eta_{l}$ 自体も平均值 0 の白色雑音であると仮定する.

式（4）に式（1）および（3）を代入して整理する $\varepsilon$, 次式が得られる.

$$
\begin{aligned}
& y_{l}=c_{l} p_{l}+d_{l} q_{l}-c_{l+1} p_{l+1}-d_{l+1} q_{l+1}+\varepsilon_{l} \\
& \text { ここに } \\
& y_{l}=\sum_{t=s_{l}}^{u_{l}}\left\{o_{l}(t)-i_{l}(t)\right\} \\
& \varepsilon_{l}=\eta_{l}+\sum_{t=s_{l}}^{u_{l}}\left\{\zeta_{l}(t)-\zeta_{l+1}(t)\right\}
\end{aligned}
$$

である. また, $p$ は非渋滞時の計数値 $m$ の和, そして $q$ は渋滞時の計数値 $m$ の和である. 誤差項 $\zeta_{l}(t), \zeta_{l+1}$ $(t)$, および $\eta_{l}$ は互いに無相関であると仮定する.

式 (5) を路線上に隣接する各断面における感知器計 数値に適用すると, 各断面の補正係数 $c_{l}$ および $d_{l}$ を末 知数とする連立方程式が得られる. 式（5）の計数開始 時刻 $u_{l}$ および終了時刻 $s_{l}$ は, 隣接断面のおのおのの対 において任意に定めることができる. したがって, 車両
感知器の故障などのために通過台数の計数が一時中断し たときには, もし中断時に泳滞していれば渋滞時の計数 值を時間的にさかのぼって破棄し, それ以前の連続計数 值に対して式（5）を適用すればよい. 中断後の計数値 の取扱いも同様にすればよい.

式 $(5)$ の誤差項 $\varepsilon_{l}$ の分散および共分散は, $\zeta_{l}(t)$, $\zeta_{l+1}(t)$ および $\eta_{l}$ が互いに独立な白色雑音であるとの 仮定と, 式（5）および式（7）とから, 以下のように 評価できる.

$$
E\left\{\varepsilon_{l}^{2}\right\}=E\left\{\eta_{l}^{2}\right\}+\sum_{t=s l}^{u_{l}}\left[E\left\{\zeta_{l}^{2}(t)\right\}+E\left\{\zeta_{l+1}^{2}(t) \mid\right]\right.
$$

$$
\begin{aligned}
& E\left\{\varepsilon_{l-1} \varepsilon_{l}\right\}=E\left\{\varepsilon_{l} \varepsilon_{l-1}\right\}=-\sum_{t=s_{l}}^{\nu_{l}} E\left\{\zeta_{l}^{2}(t)\right\} \cdots \\
& E\left\{\varepsilon_{l-m} \varepsilon_{l}\right\}=E\left\{\varepsilon_{l} \varepsilon_{l-m}\right\}=0, \quad m \neq 0,1 \cdots
\end{aligned}
$$

となる.ここに $E$ は期待値を示す. さらに， $S_{l}$ および $U_{l}$ は, 断面 $l-1$ および $l$ における計数時間と, 断面 $l$ および $l+1$ における計数時間とに重複がある場合に, その重複の開始時刻および終了時刻とをそれぞれ示す.

各誤差項について, 以下のように仮定する.

(1) 補正誤差 $\zeta_{l}(t)$ は, 計数値 $m_{l}(t)$ に比例する.

(2) 区間内の車両台数差による誤差 $\eta_{l}$ は, 下流断面 における計数開始時および終了時の計数值 $m_{l+1}(t)$ の 差に比例する.

これらの仮定から, 式（８）および（9）は計数值 $m$ により次式のように表わせる.

$$
\begin{aligned}
E\left\{\varepsilon_{l}^{2}\right\}= & \alpha^{2}\left\{m_{l+1}\left(s_{l}\right)-m_{l+1}\left(u_{l}\right)\right\}^{2} \\
& +\beta^{2} \sum_{t=s_{l}}^{u_{l}}\left\{m_{l}^{2}(t)+m_{l+1}^{2}(t)\right\}
\end{aligned}
$$

$$
E\left\{\varepsilon_{l-1} \varepsilon_{l}\right\}=E\left\{\varepsilon_{l} \varepsilon_{l-1}\right\}=-\beta^{2} \sum_{t=S_{l}}^{v_{l}} m_{l}^{2}(t)
$$

ここに, $\alpha$ および $\beta$ は比例定数である.

なお, インターチェンジにおける分流部および合流部 についても，本節と同様に定式化することができる.

（） アップディティング・アルゴリズム

本節では, 車両感知器からの交通デー夕を 1 日分記憶 しておき，これを夜間に 1 日 1 回の割りで処理し, 補正 係数值を推定・更新するアルゴリズムを導く. 交通デー 夕の処理周期をこのように定めたのは, 以下のような理 由による.

(1) 各車両感知器の偏りの時間変化は緩やかであると 考えられるから，それほど頻繁に補正係数值を更新する 必要はない.

(2) 交通データの処理周期をあまり長くすると, 所要 デー夕記憶容量が増大し, オンライン処理に適さなくな る.

(3) 交通現象の再現周期と交通デー夕の処理周期を一 
致させることにより, 補正係数值の推定精度を改善でき る.

(4) 夜間は管制用計算機システムの負荷が比較的軽 い.

通常用いられる最小二乗法についても，算法を工夫す ることにより, 逐次処理アルゴリズムが導かれている. したがって, それを連立方程式（5）に適用して計数値 を 1 日 1 回ずつ処理し, 補正係数 $c_{l}$ および $d_{l}$ の值を漸 化的に改良していくこともできる，ただし，この方法は 補正係数が常に一定の值をとることを前提としている. 一方，3.において述べたように，補正係数值は実際に は経時変化するものとみなす必要がある．これに対応す るためには, 補正係数 $c_{l}$ および $d_{l}$ の推定誤差共分散行 列の要素の值を定期的に調整するなどの補助的操作が必 要となる.このような操作はオンライン処理には必ずし も適してはいない. そこで,ここでは時系列解析法の 1 つであるカルマン・フィルタリング・アルゴリズムを適 用し, 補正係数值の経時変化に対応でき，かつオンライ ン処理にも適した推定・更新アルゴリズムを導く.

離散時間カルマンフィルターは, 次式のように差分式 で表わされるシステムの状態の最小二乗推定量を与え $る^{10), 11)}$.

$$
\begin{aligned}
& x(k+1)=F(k) x(k)+G(k) w(k) \\
& y(k)=H(k) x(k)+v(k) \cdots \cdots \cdots \cdots
\end{aligned}
$$

ここに, $k$ は時間，ここでは特に日を示すものとする. また, $x(k)$ はシステムの状態を示す $n$ 次元ベクトル， $y(k)$ は $p$ 次元の計測值ベクトル, $w(k)$ および $v(k)$ は白色雑音べクトル, そして $F(k), G(k), H(k)$ は 要素の值が既知の係数行列である. 式 (13) の状態ベク トル $x(k)$ は直接には計測できない. しかし，式 (14) に示されるように, $x(k)$ の線形変換である $y(k)$ は, 計測誤差を伴うものの直接計測することができる.

更新開始日から $k$ 日後までの計数值 $y(0), y(1)$, $\cdots, y(k)$ が得られたときの, システムの $k$ 日後の状態 $x(k)$ の最小二乗推定量を, $\hat{x}(k / k)$ で示すことにする. 推定量 $\hat{x}(k / k)$ は不偏であり, かつ推定誤差共分散行列 $P(k / k)=E\left\{[x(k)-\hat{x}(k / k)][x(k)-\hat{x}(k / k)]^{\top}\right\}$ を最小化する. 更新開始日から $k-1$ 日後までの計数值 $y(0), y(1), \cdots, y(k-1)$ に基づく, $k$ 日後の状態 $x$ ( $k$ ) の推定量 $\hat{x}(k / k-1)$ は, $k$ 日後に得られる計数 値 $y(k)$ により，次式のように改良することができる.

$$
\begin{aligned}
\hat{x}(k / k)= & \hat{x}(k / k-1) \\
& +K(k)[y(k)-H(k) \hat{x}(k / k-1)]
\end{aligned}
$$

ここに係数ベクトル $K(k)$ はカルマンゲインとよばれ, この要素の值はカルマン・フィルタリング・アルゴリズ ムにより与えられる.

ここで, 更新開始日から $k$ 日後の補正係数値, 1 日分
の計数値, あるいは䛊差項などを, 以下のように置き換 える。

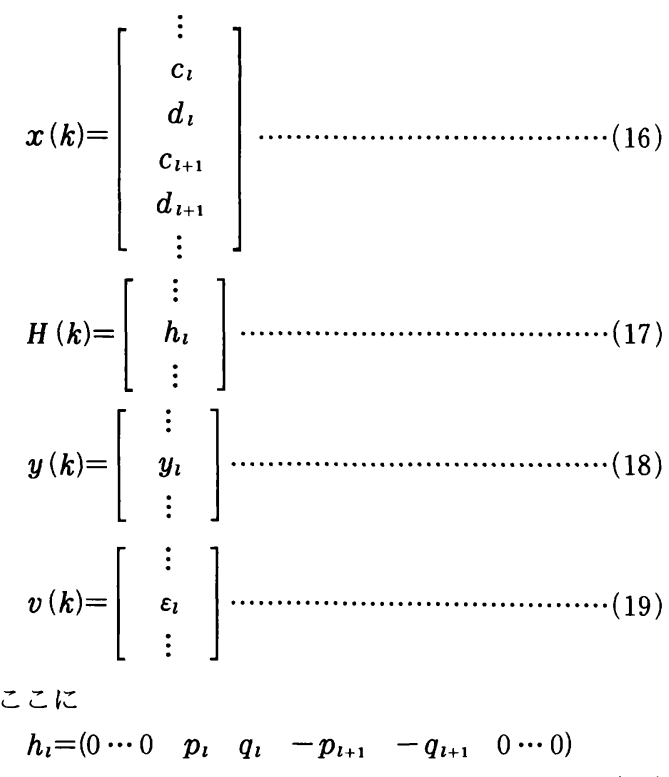

である.このとき連立方程式（5）は

$$
y(k)=H(k) x(k)+v(k) \cdot
$$

と表わせる. さらに, 補正係数值が毎日少しずつ変化し ていくものと仮定し，それを次式で表わす.

$$
x(k+1)=x(k)+w(k) \cdots
$$

ここに, $w(k)$ は補正係数値の日変動幅を規定する項 であり，白色雑音要素からなるべクトルである．

式 (22) は, 式 (13) において $F(k)$ および $G(k)$ を単位行列に置き換えたものである. また, 式 (21) は, 式（14）とまったく等しい形をしている. したがって, 式 (21) および (22) にカルマン・フィルタリング・ア ルゴリズムを適用することにより, 補正係数の值をシス テムの状態変数として, 毎日逐次的に推定・更新するこ とができる.

カルマンフィルターの基本アルゴリズムには, 白色雑 音ベクトル $v(k)$ の共分散行列 $R$ の逆行列演算が含ま れる. 感知器設置断面数を $r$ とすると, 共分散行列 $R$ の寸法は少なくとも $r \times r$ となるから，道路網全体で はかなり大きくなる. そのうえ, 行列 $R$ は非対角行列 であるため, 基本アルゴリズムをこの問題にそのまま適 用すると, 計算時間や計算精度の面で実用上の支障が生 ずる可能性もある. しかし，この逆行列演算を基本アル ゴリズムの小改修により避け得ることが，すでに示され ている11).

\section{6. 渋滞の検出方法}

前節の方法により車両感知器の補正係数を推定するに 
は, 各車両感知器設置断面において渋滞を検出する必要 がある。

渋滞検出法の 1 つとして, 自由流と渋滞流との境界領 域における交通状況の発生頻度が, そのほかの領域にお ける発生頻度に比べてかなり小さいという特性 ${ }^{12)}$ を応用 する方法がある. すなわち, 交通デー夕を蓄積して自由 流と渋帯流の境界領域において出現頻度が最小の速度 (たとえば $45 \mathrm{~km} /$ 時) を求め, それより高速の流れを 自由流, 低速の流れを渋滞流とする方法である ${ }^{9), 13)}$. ま た, この渋滞検出のための䦨値を車両感知器デー夕に基 ブいてオンラインで自動的に更新するアルゴリズムも, 著者が提案している ${ }^{9)}$. 本研究では,この渋滞検出法を 採用している.

\section{7. 適用結果}

補正係数のアップデイティング・アルゴリズムを, 首 都高速道路 3 号上り線に適用した. 使用した感知器デー 夕の詳細を表一2に示す.

5. (1) に示した通過台数つ計数規準@〜(C)を満足す る計数値の組は, 各隣接断面の対において表一3に示す ように得られた。

表一3 の計数值に, 以下に示すような条件で補正係数 のアップデイティング・アルゴリズムを適用した.

(1) 補正係数の初期值は, すべて 1.0 とした.

(2) 補正係数の推定誤差分散の初期値は, すべて 1.0 とした.

\section{表一2 感知器データの仕様}

\begin{tabular}{|c|c|}
\hline 测定項目 & $\begin{array}{l}\text { 交通量 } \\
\text { 空谓平均速度または時阔オキュバンシー }\end{array}$ \\
\hline 菓录卜時泪単位 & 5 分 \\
\hline 収集時間 & $6: 00 \sim 17: 00$ \\
\hline 収集期间 & $\begin{array}{l}\text { 1982年11月1日～12月12日 } \\
\text { (11月8日－11月22日は欠測) }\end{array}$ \\
\hline
\end{tabular}

\section{表一3 補正係数の推定に使用した計数俌の組}

\begin{tabular}{|c|c|c|c|c|c|c|}
\hline \multirow[b]{2}{*}{ 断面 } & \multicolumn{2}{|c|}{ 車画盛知器番号 } & \multirow{2}{*}{$\begin{array}{l}\text { 計数值 } \\
\text { の粗数 }\end{array}$} & \multicolumn{3}{|c|}{ 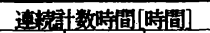 } \\
\hline & $\begin{array}{l}\text { 荇 } \\
\text { 連貌 }\end{array}$ & 連車楼 & & 平均 & 最大 & 最小 \\
\hline 1 & \multicolumn{2}{|c|}{$\mathrm{T}-32^{\circ}$} & 12 & & 110 & \\
\hline 2 & 643 & 644 & & & & 1.0 \\
\hline 3 & 633 & 634 & 40 & 4.9 & 11.0 & 1.2 \\
\hline 4 & 40 & 60 & 26 & 4. 2 & 11.0 & 1.0 \\
\hline 4 & 023 & 626 & 22 & 5.4 & 11.0 & 1.2 \\
\hline 5 & 623 & 624 & 20 & 3.0 & 11.0 & 1.3 \\
\hline 6 & 613 & 614 & 18 & 3.6 & 11.0 & 1.2 \\
\hline 7 & 607 & 608 & 25 & 8.1 & 11.0 & 1.0 \\
\hline 8 & 603 & 604 & 16 & 7.6 & 11.0 & 1.5 \\
\hline 9 & 595 & 597 & 18 & 7.8 & 11.0 & 2.0 \\
\hline 10 & 589 & 590 & 28 & 6.1 & 11.0 & 1.1 \\
\hline 11 & 124 & 125 & 19 & 7.2 & 10.9 & 1.0 \\
\hline 12 & 133 & 134 & & & & \\
\hline
\end{tabular}

注） $\mathrm{T}-32^{*}$ : 本楾料金所(用賀)のトラフィック・カウンター
(3) 区間内の車両台数差による誤差を, 計数開始時之 終了時における計数值の差の $20 \%$ と仮定し, 式 (11) において $\alpha=0.2$ と設定した.

(4) 補正誤差を計数値の $10 \%$ と仮定し, 式 (11) お よび (12) において $\beta=0.1$ と設定した.

(5) データ収集期間が約 4 週間と短いので, この期間 中には補正係数は変動しないものとみなし, 式 (22) に おいて補正係数の日変動を示す項 $w(k)=0$ とした.

(2)～(5)については必ずしも実際の值を与える必要はな く, その相対的大小関係を適切に設定すればよいことが 示されている14). したがって, 収束速度を多少犠牲にし てでも,これらに大きめな值を与えて推定值の急激な変 動を抑えることが，実用的な方策であると考えられる. また, パラメーター值の長期変動を追跡していくことが アップデイティングの目的であるから, 特に高い収束速 度は必要ない.このため, (2)〜 (4)における設定值も, 実 際の値よりも多少大きめにした.

図一3に示す自由流側の交通量-交通密度相関を直線 で近似すると, 交通量の変動 1 に対する密度の変動はお おむね 0.2 と見積られる. したがって, 平均区間長を首 都高速道路の平均感知器設置間隔（デー夕収集当時）で ある $0.6 \mathrm{~km}$ とすると, 交通量の変動 1 に対する区間内 車両台数の変動は $0.2 \times 0.6=0.12$ と見積られる. これ に加えて交通量が同じであっても密度が変動することも 考虑し, 区間内の車両台数差による誤差を, 計数開始時 亡終了時における計数值の差の $20 \%$ と仮定した.

図一4 は, 各断面の渋滞時用の補正係数值が更新され た過程を示している. 更新されるにつれて係数値の動き も安定し, 後半ではほぼ一定値に収束している. また, 初期から変動が小さい係数と, 值の正負を問わず変化の 大きい係数に大別できる. 後者の変動の理由は, 該当す る断面において推定初期に有効な計数值が十分に得られ

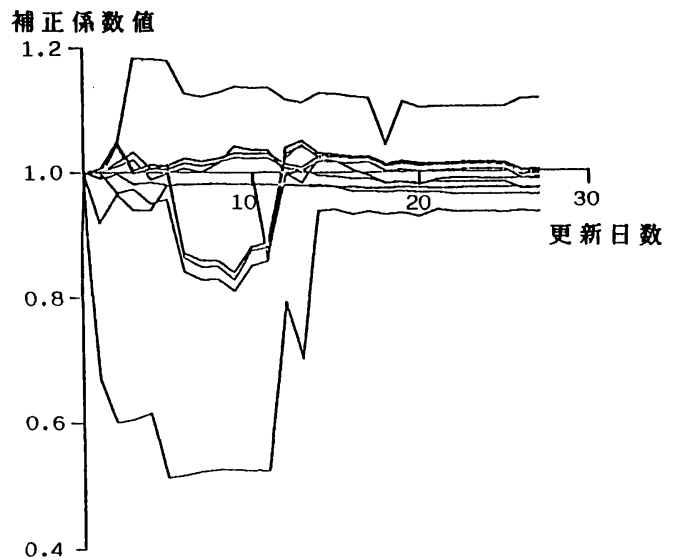

図一4 渋滞時補正係数の更新過程 
なかったためであると考えられる. 同じデータを繰り返 しアップデイティング・アルゴリズムに適用し, 各回に おいて $y(k)-H(k) x(k)$ のユークリッド・ノルムを 前回と比較することで, 各回における収束度を判断でき $3^{14)}$. 2 回目の 1 回目に対するユークリッド・ノルムの 減少率は各断面において $0.1 \%$ 末満であり, 初回でほ ぼ収束しているとみなせる。

図一 5 には，この補正係数の収束値の逆数から 1 を差 し引くことにより, 各断面における偏りを渋滞時および 非渋滞時の別に計算した結果を示す．渋滞時と非渋滞時 とでは, 偏りの発生状況が，明らかに異なっている．非 渋滞時には, 各断面でほぼ共通して過小計数となってい るが，偏りの大きさそのものは各断面において高々 $2 \%$ 程度である. 渋滞時には, 断面 6 (車両感知器番号 613 , 614）を除くと, 各断面でほぼ共通して過剩計数となっ ている. そして, 非渋滞時と比べてかなり偏りが大きく, $10 \%$ を越える断面もみられる.

図一6に, 断面 6 における車両感知器の設置状況之, 車線変更車両の走行軌跡の概念図を非渋滞時および橴滞 時の別に示す．非渋滞時には，走行速度が比較的高くか つ車両間に合流に適した間隙が相対的に多いため，車線 が 3 車線から 2 車線に絞られる地点のかなり手前から車 線変更が開始される. 逆に渋滞時には, 走行速度が低く かつ車両間に合流に適した間隙が少ないため，車両感知 器が設置された地点を越えてから，かなり急な角度で車 線を変更する車両が多くみられる．このような車両が車 両感知器に感知されないことが, 渋滞時の断面 6 におけ るかなり大きな過小計数の原因であると考えられる.

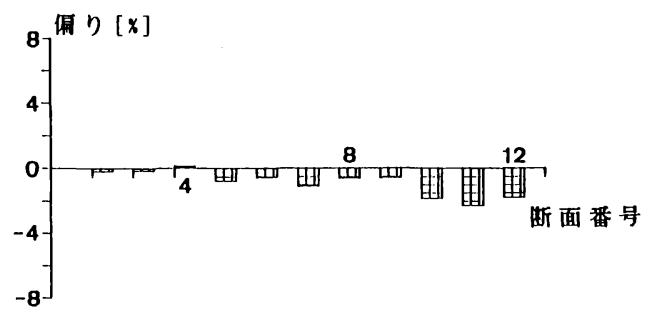

（a）非渋滞時

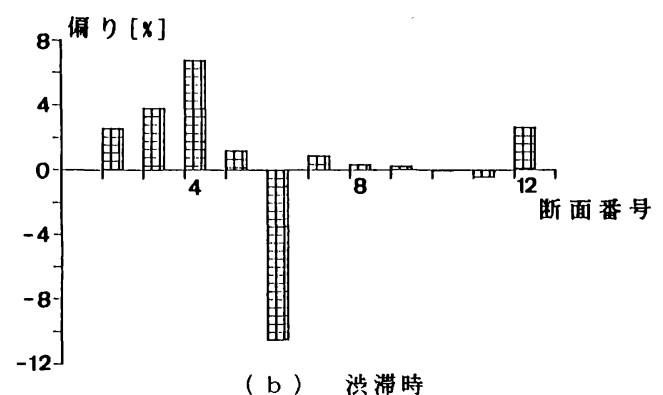

(b) 涉滞時

図一5 補正係数值に基づいて計算した各断面の偏り
渋滞時および非渋滞時の区別をしなければ，上下流断 面における計数值を順次掛け合わせていくことにより， 各断面における偏りを推定できる.このとき，本線料金 所における計数值の偏りは, 零と仮定する. 図一7は, このようにして推定した偏りを, 補正前と補正後とにつ いて示したものである.

補正の効果は明らかであり，実用上十分な精度が得ら れている.しかし，各断面において補正後に $-0.2 \%$ 程度の偏りがほぼ共通してみられる。これは，本線料金 所においても, $\pm 0.3 \%$ 程度の誤差は許容されており, 実際にも偏りがあることが，主な原因であると考えられ る. 補正係数を推定するときには，本線料金所における 計数誤差分散を大きめに設定することにより，上記の程 度の偏りは補正できていると考えられる.しかしながら， 本推定法からは補正した值を直接に求めることができな いこと，およびこの例と後出の図一8に示す例とを比較 する必要があることから,ここでは本線料金所における 偏りを零と仮定した結果を図示する.
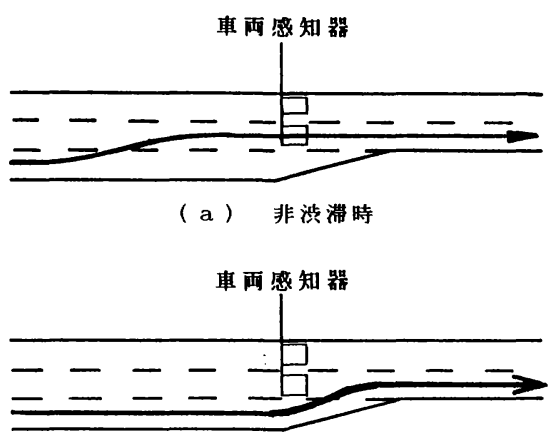

(b) 泚滞時

図一6断面 6 付近における車線变更車両の走行軌跡

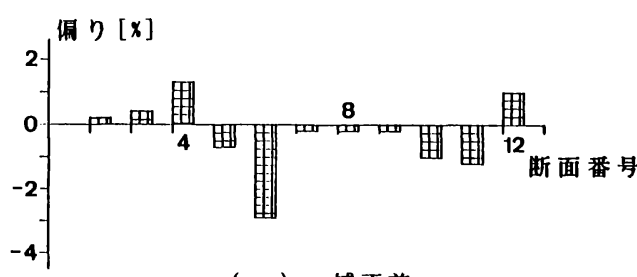

（a）補正前

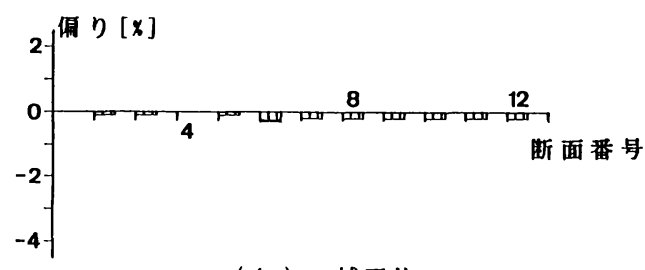

（b）補正後

図一7 補正前後における偏りの比較 
表一4 検証用感知器データの仕様

\begin{tabular}{|c|c|}
\hline 測定項目 & $\begin{array}{l}\text { 交通量 } \\
\text { 空间平均速度または時間オキュパンシー }\end{array}$ \\
\hline 集計時間単位 & 1分(5分単位に集計して使用した。) \\
\hline 収集時間 & $6: 00 \sim 19: 00$ \\
\hline 収集期周 & $\begin{array}{l}\text { 1982年12月20日 12月30日 } \\
\text { (12月22日と12月27日は欠測) }\end{array}$ \\
\hline
\end{tabular}

表一5 㭪正係数の検証に使用した計数値の組

\begin{tabular}{|c|c|c|c|c|c|c|}
\hline \multirow{2}{*}{$\begin{array}{l}\text { 断面 } \\
\text { 番号 }\end{array}$} & \multicolumn{2}{|c|}{ 重西感知器番号 } & \multirow{2}{*}{ 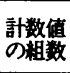 } & \multicolumn{3}{|c|}{ 連綐意十数時間[時闻] } \\
\hline & $\begin{array}{l}\text { 走行 } \\
\text { 䡕 }\end{array}$ & 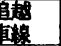 & & 平均 & 最大 & 最小 \\
\hline 1 & \multicolumn{2}{|c|}{$\mathrm{T}-32^{\circ}$} & & & & \\
\hline 2 & 643 & 644 & 10 & 3.9 & 1L.5 & 1.3 \\
\hline 3 & 633 & 634 & 18 & 3.5 & 13.0 & 1.0 \\
\hline 4 & 625 & 626 & 14 & 4.5 & 13.0 & 1.1 \\
\hline 5 & 663 & 624 & 12 & 5.3 & 13.0 & 1.0 \\
\hline 6 & 6 & 664 & 7 & 5.8 & 12.9 & 1.0 \\
\hline 7 & 6 & 017 & 5 & 8.4 & 12.9 & 1.3 \\
\hline 8 & 001 & 000 & 7 & 8.3 & 12.9 & 6.3 \\
\hline 9 & 595 & 5 & 8 & 9.3 & 13.0 & 6.5 \\
\hline 10 & 589 & 500 & 8 & 9.4 & 13.0 & 6.4 \\
\hline 11 & 124 & 125 & 6 & 8.7 & 13.0 & 4.9 \\
\hline 12 & 133 & 134 & 4 & 7.6 & 12.8 & 1.0 \\
\hline
\end{tabular}

注） T-32・：本線料金所(用賀)のトラフィック・カウンター

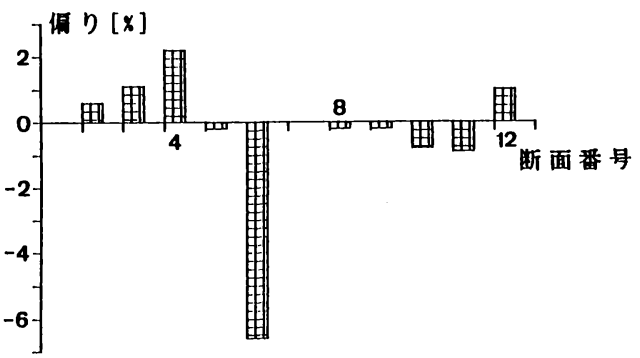

(a) 補正前

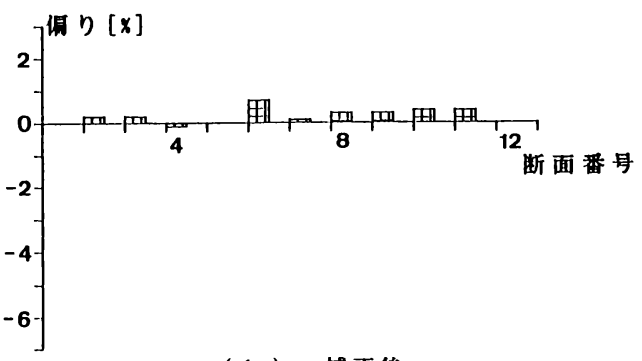

(b) 補正後

図一8 補正前後における偏りの比較（検証用データ）

図一8には，表一 2 および表一 3 に示すデータに基づ いて決定した補正係数值により，表一4および表一 5 に 示す異なる時期に収集された計数値を補正し，図一7 と 同じ方法により各断面における偏りを推定した結果を示 す。補正することにより，各断面において偏りを高々 $1 \%$ 程度には抑えることができる. 各断面において補
正後に+0.3\% 程度の偏りがほぼ共通してみられる原 因は，図一7 の場合と同様であると考えられる.

表一2 および表一 3 に示した首都高速道路 3 号上り線 の約 4 週間分のデータを処理するのに要した時間 ( $\mathrm{cpu}$ time) は, 東京大学生産技術研究所電子計算機室の FACOM M-380 Q 上で約 8 秒と十分短く, 都市高速道 路網における実用化が十分に可能であると考えられる.

\section{8. ま と め}

本研究では, 車両感知器により計数された通過車両台 数の偏りを補正するために，最適係数値を推定・更新す る計算機アルゴリズムを開発した．本アルゴリズムの特 徵は以下のようにまとめられる.

（1）車両感知器データに基づいて, 各感知器設置断 面ごとに，かつ渋滞時および非渋滞時の別に最適な補正 係数值を与える.

（2）補正係数の初期設定值の精度が多少低くとも， その精度を逐次改善することにより実用上十分な精度を 達成し，さらにその精度を維持することができる.

（3）渋滞検出の結果を利用して, 推定精度を向上さ せている.

（4）車両感知器デー夕を逐次処理する方式であるた め, 計算時間および所要主記憶容量は十分に小さく, 都 市高速道路網におけるオンラインでの実用化が可能であ る.

このアルゴリズムを首都高速道路 3 号上り線に適用し た結果, 通過車両台数を実用上十分な精度で補正するこ とができた．また，偏りの発生状況について，以下が推 定された.

（1）偏りは感知器設置断面ごとにかなり異なる.

（2）非渋滞時には，各断面でほぼ共通して過小計数 となっているが, 偏りの大きさそのものは各断面におい て高々 $2 \%$ 程度である.

（3）渋滞時には，各断面でほぼ共通して過㮃計数と なっている. 非渋滞時と比べてかなり偏りが大きく, $2 \%$ を越える断面が数か所みられた.

画像処理技術等を応用した新しい夕イプの交通流セン サにより，本線上の断面においても通過車両台数を高精 度に計数することができる可能性がある．いくつかの断 面において高精度の計数值が得られれば，それらを料金 所における計数值とともに本アルゴリズムにおける基準 值として用いることにより，より高い精度の補正係数值 を与えることができると考えられる.

最後に, 本研究を進めるにあたり首都高速道路公団か ら車両感知器データの提供, その他の協力を得たことを 記し，謝意を表わす。 
参 考 文 献

1）首都高速道路協会：交通管制システムの性能実験報告書, 1970.

2) 井上廣胤：車両感知器とその評価, 交通工学, Vol. 2, No. 3, pp. 1 7, 1967.

3）池之上慶一郎・松永典照・渡辺正己：車両感知器による 交通流計測の評価について, 科学警察研究所報告, Vol. 12, No. 1, pp. 1 12, 1971.

4）松永典照・岩本三郎・笹島喜雄：杤木県警察本部交通管 制システムのパイロット実験報告, 科学警察研究所報告, Vol. 13, No. 1, pp. 61 70, 1972.

5）中过 隆・加来照俊：区分的な定常性を考慮した都市内 街路の交通状態の予測について, 土木計画学研究, No.4, pp. 101 108, 1986.

6) 首都高速道路公団, 交通工学研究会: 首都高速道路の将 来管制システムに関する研究 (その 3$), 1984$.

7）赤羽弘和：都市高速道路管制システムのパラメータ・ アップデイティング, 東京大学学位論文, 1986.

8) Akahane, H. and Koshi, M. : Sort-term Prediction of Inflow Volumes of Urban Freeways, Proceedings of
I. E. E. Second International Conference on Road and Traffic Control, pp. 35 38, 1986.

9) Akahane, H. and Koshi, M. : Updating of Volume Density Relationships for an Urban Expressway Control System, Proceedings of the Tenth International Symposium on Transportation and Traffic Theory, pp. 339 $356,1987$.

10) Kalman, R.E. : A New Approach to Linear Filtering and Prediction Problems, Trans. ASME, J. of Basic Eng., Vol. 82 D, No. 1, pp. 35 45, 1960.

11）片山 徹: 応用カルマンフィル夕, 朝倉書店, 1983.

12）越 正毅・岩崎征人・大蔵 泉・西宮良一：渋滞時の交 通流現象に関する研究, 土木学会論文報告集, No. 306, pp. 59 70, 1981.

13）越 正毅・岩崎征人・大蔵 泉：高速道路における渋滞 検出精度の改善に関する研究, 土木学会論文報告集, No. 330, pp. 121 127, 1983.

14）砂原善文編：確率システム理論 III応用編，朝倉書店, 1982.

(1988.8.15 - 受付) 